\title{
COST-EFFECTIVENESS ANALYSIS OF PERCUTANEOUS CORONARY INTERVENTION VERSUS THROMBOLYTIC THERAPY IN PATIENTS WITH AN ST-ELEVATED MYOCARDIAL INFARCTION
}

\author{
Grubor Iva
}

${ }^{1}$ University in Kragujevac, Medical Faculty, Kragujevac, Serbia

\author{
ANALIZA ODNOSA TROŠKOVA/KLINIČKE EFIKASNOSTI PERIKUANE \\ KORONARNE INTERVENCIJE I PRIMENE TROMBOLITIKA \\ KOD PACIJENATA SA AKUTNIM INFARKTOM \\ MIOKARDA SA ST ELEVACIJOM \\ Grubor Iva ${ }^{1}$ \\ Univerzitet u Kragujevcu, Medicinski fakultet, Kragujevac, Srbija
}

Received / Primljen: 16. 10. 2011.

Accepted / Prihvaćen: 21. 11. 2011.

\section{ABSTRACT}

Background/aim: An acute myocardial infarction is a life-threating condition that requires urgent hospitalisation and medical treatment. An ST-elevated myocardial infarction indicates a much larger degree of myocardial necrosis and should be treated with reperfusion strategies, such as percutaneous coronary intervention or thrombolytic therapy. The aim of the study was to economically evaluate these treatment methods and determine of their cost effectiveness.

Methods: A Markov model was developed using the TreeAge ${ }^{\circ}$ software and was based on data of effectiveness and local Serbia cost calculations in the literature. The duration of one cycle was one year, and the time horizon was set to 40 cycles, i.e., 40 years. The costs and outcomes were discounted by 3\% annually. A Monte Carlo simulation was performed with 1000 virtual patients, as well as a sensitivity analysis, represented by a Tornado diagram, in which the values were varied by $\pm 50 \%$.

Results: Percutaneous coronary intervention is not a cost-effective treatment for ST-elevated myocardial infarctions. Treatment with thrombolytic therapy, i.e., streptokinase, had a better cost-effectiveness ratio given that PCI is two times more expensive per one quality adjusted life year gained, 76558, $11 \mathrm{rsd} / \mathrm{Q} A L Y$ for PCI vs. $37263 \mathrm{rsd} / \mathrm{Q} A L Y$ for thrombolytic therapy. Even after parameters varying by

\section{ABBREVIATIONS:}

RSD- Republic of Serbia dinars QALY- Quality-Adjusted Life Years PCI- Percutaneous Coronary Intervention

USA- United States of America SIGN- Scottish Intercollegiate Guidelines Network ICER-Incremental Cost-Effectiveness Ratio CABG -Coronary Artery Bypass Graft

\section{SAŽETAK}

Uvod/cilj: Akutni infarkt miokarda je životno ugrožavajuće stanje koje zahteva urgentnu hospitalizaciju $i$ adekvatnu medikamentnu terapiju. Ukoliko postoji elevacija ST segmenta koja ukazuje na nekrozu čitave debljine zida miokarda, najčešće je potrebna hitna revaskularizacija, bilo u vidu primene trombolitika ili perkutane koronarne intervencije. Cilj ove studijeje bio upoređenje ove dve metode lečenja sa farmakoekonomskog aspekta, odnosno upoređenje odnosa troškova/kliničke efikasnosti primene trombolitika i perkutane koronarne intervencije.

Metod: Za potrebe ove farmakoekonomske analize uradeno je modeliranje u TreeAge ${ }^{\circ}$ softveru, bazirano na podacima iz literature o efikasnosti i izračunavajući troškove lečenja u Republici Srbiji. Trajanje jednog ciklusa je godinu dana, dok je vremenski horizont podešen na 40 ciklusa, tj.40 godina. Uradena je Monte Karlo simulacija sa 1000 virtuelnih pacijenata, kao $i$ analiza senzitivnosti, predstavljena tornado dijagramom, $u$ kojoj su vrednosti parametara varirane $z a \pm 50 \%$.

Rezultati: Primena perkutane koronarne intervencije $u$ lečenju akutnog infarkta miokarda sa ST elevacijom se pokazala kao neisplativa, sa lošijim odnosom troškova/kliničke efikasnosti od primene trombolitika, odnosno streptokinaze. Ova metoda lečenja je oko dva puta skuplja po dobijenoj godini života korigovanoj za kvalitet od trombolitika $(76558,11$ rsd /QALY za perkutanu koronarnu intervenciju naspram 37263 rsd/QALY za primenu trombolitika). Variranjem vred-

\section{SKRAĆENICE:}

RSD- dinar Republike Srbije;

QALY - godine života korigovane za kvalitet;

PCI- perkutana koronarna intervencija;

USA-Sjedinjene Američke Države;

SIGN- Škotske nacionalne smernice lečenja;

ICER-Odnos inkrementalnih troškova i inkrementalne efikasnosti;

CABG- Koronarni arterijski bajpas graft. 
$\pm 50 \%$, PCI did not become an economically viable treatment with positive net benefits.

Conclusion: Our results indicated that acute myocardial infarctions with ST elevations should be treated with thrombolytic therapy because of its higher clinical effectiveness and lower costs. The aim of the further analyses should identify the patients with acute myocardial infarctions in Serbia whose condition would economically justify the use of PCI.

Keywords: acute myocardial infarction, percutaneous coronary intervention, thrombolytics, cost-effectiveness analysis.

\section{INTRODUCTION}

Currently, one of the main causes of mortality and morbidity in industrial countries is ischemic heart disease. More than 800 thousand people in the world suffer from this problem. For most of them, ischemic heart disease progresses to severe acute unstable coronary syndrome with a large degree of necrosis of myocardial tissue, i.e., an acute myocardial infarction. In the US, over 3 million people annually survive myocardial infarctions.[1] These outcomes are similar in Serbia, where the incidence of ischemic heart disease in 2009 was 643,81 per 100000 people and 712,27 per 100000 people in the Sumadija region. [2] According to data available from the Republic Institute of Public Health website, 16805 people had myocardial infarctions, of which 5016 died in 2007.[3] The latest information indicates that the mortality rate from myocardial infarctions is $5,9 \%$ in the $0-75$ year age group and $8,2 \%$ in the 20-64 year age group. [2]

The World Health Organization has noted that a myocardial infarction is a life-threatening condition that affects a patient's quality of life. This fact is confirmed by high rates of mortality, despite new therapeutic approaches for the treatment of this condition. Studies have shown that $30-50 \%$ of patients die within the first two hours after symptoms of a myocardial infarction appeared. The administration of adequate therapy, i.e., thrombolytic therapy or coronary intervention with adjuvant drugs (glycoprotein IIb/ IIIa inhibitors), can reduce the mortality of myocardial infarctions. In fact, after creating coronary care units, performing coronary interventions and administrating appropriate therapy (thrombolytics), the early mortality rate has decreased to $6-7 \%$.[1] nosti troškova i kliničke efikasnosti stanja za $\pm 50 \%$, perkutana koronarna intervencija nije dobila na isplativosti.

Zaključak: Naša studija je pokazala da je u farmakoekonomskom smislu povoljnija primena trombolitika u lečenju infarkta miokarda sa ST elevacijom, usled veće efikasnosti $i$ manjih troškova. Dalja istraživanja su usmerena ka selektiranju pacijenata kod kojih bi primena perkutane koronarne intervecije bila ekonomski isplativa.

Ključne reči: Akutni infarkt miokarda, perkutana koronarna intervencija, trombolitici, analiza odnosa troškova/ kliničke efikasnosti.
An acute myocardial infarction is an urgent condition that requires hospitalisation in an intensive care unit. Thus, costs can be divided in four main categories: the cost of hospitalisation, the cost of appropriate pharmacotherapy, the cost of the revascularisation method and the cost of possible compli-

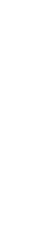


cations.[4] The aim of this research was to determine the cost-effectiveness ratios of two revascularisation methods used in the treatment of acute myocardial infarctions: percutaneous coronary intervention and thrombolytic therapy.

\section{MATERIAL AND METHODS}

For the purpose of our study, we developed a Markov model using the TreeAge Pro ${ }^{\circ}$ software [5] to compare the cost-effectiveness ratios of two therapeutic strategies used in acute ST-elevated myocardial infarctions. These strategies include percutaneous coronary intervention and intravenous administration of a thrombolytic drug or, for this study, streptokinase. The model was designed according to the model used in the study by Vegrel, Palmer, Asseburg et al. [6] In our analysis, we divided the patients with myocardial infarctions into four health states: alive with heart insufficiency, nonfatal myocardial infarction, nonfatal stroke and death. All health states could transition to other states or to death. The necessary data for the probabilities and the clinical effectiveness were taken from Vergel, Palmer, Asseburg et al. [6] and other valid clinical trials. [7,8] Data are shown in Table 1, and the model structure is presented in Figure 1.

The duration of one cycle in the model was set to one year. The time horizon was 40 cycles or 40 years. The study involved analyszinged the direct costs, such as hospitalisation expenses, and the health-state treatment costs determined using the SIGN (Scottish Intercollegiate Guidelines Network) guidelines for the treatment of myocardial infarction [9], stroke [10] and heart insufficiency [11]. The prices of health services and drugs were taken from the Republic Institute for Health Insurance Tariff Book.[12] Costs were expressed in 2011 Serbian dinars (RSD ). The health states' clinical effectiveness were determined from the model and expressed in quality-adjusted life years (QALY). The incremental costs and incremental effectiveness were discounted by $3 \%$ annually. The final result of the study was obtained by comparing the cost-effectiveness ratios of percutaneous coronary intervention with thrombolytic therapy, expressed in RSD per QALY. Monte Carlo simulations with 1000 virtual patients were performed where cohorts of patient passed through all hypothetical scenarios. A two-way sensitivity analysis was performed $( \pm 50 \%$ of baseline values of a variable) to validate the model results; its outcomes are shown in a Tornado diagram in Figure 4. The annual willingness to pay was set to 1500000 RSD.

\section{RESULTS}

The results of the cost-effectiveness analysis showed that thrombolytic therapy in the treatment of acute ST-elevated myocardial infarction had a better cost-effectiveness ratio, $276491,52 \pm 139130,86$ rsd for 7,42 $\pm 6,12$ QALYs (37263 rsd per QALY), compared towith percutaneous coronary intervention,
Table 1. Values of probabilities and clinical effectiveness of the health states used in the model

\begin{tabular}{|c|c|c|}
\hline Parameter & Value & $\begin{array}{l}\text { Refer- } \\
\text { ence }\end{array}$ \\
\hline \multicolumn{3}{|l|}{ Probability of health states after PCI } \\
\hline Alive with HI & 0,13 & {$[5]$} \\
\hline Nonfatal myocardial infarction & 0,25 & {$[5]$} \\
\hline Nonfatal stroke & 0,21 & {$[5]$} \\
\hline Death & 0,41 & {$[5]$} \\
\hline Revascularisation & 0,89 & [6] \\
\hline \multicolumn{3}{|l|}{ Probability of health states after thrombolytic therapy } \\
\hline Alive with HI & 0,85 & {$[5]$} \\
\hline Nonfatal myocardial infarction & 0,06 & {$[5]$} \\
\hline Nonfatal stroke & 0,02 & {$[5]$} \\
\hline Death & 0,07 & {$[5]$} \\
\hline Revascularisation & 0,32 & {$[7]$} \\
\hline \multicolumn{3}{|l|}{ Annual transient probability } \\
\hline Alive with $\mathrm{HI}$ to Alive with $\mathrm{HI}$ in the first year & $\begin{array}{l}0,844 \\
0,653 \\
0,702\end{array}$ & {$[5]$} \\
\hline Alive with $\mathrm{HI}$ to Alive with $\mathrm{HI}$ in the second+ year & $\begin{array}{l}0,914 \\
0,865 \\
0,914\end{array}$ & {$[5]$} \\
\hline Alive with HI to Nonfatal CV event in the first year & 0,059 & {$[5]$} \\
\hline Alive with $\mathrm{HI}$ to Nonfatal CV event in the second+ year & 0,027 & [5] \\
\hline Alive with HI to Death in the first year & 0,038 & {$[5]$} \\
\hline Alive with HI to Death in the second+ year & 0,032 & [5] \\
\hline Nonfatal CV event to Death in the first year & 0,26 & {$[5]$} \\
\hline Nonfatal CV event to Death in the second+ year & 0,048 & {$[5]$} \\
\hline Nonfatal MI to Nonfatal CV event & 0,087 & [5] \\
\hline Nonfatal stroke to Nonfatal CV event & 0,038 & [5] \\
\hline \multicolumn{3}{|l|}{ Probability of revascularisation } \\
\hline Repeated PCI after primary PCI & 0,5 & {$[5]$} \\
\hline CABG after primary PCI & 0,5 & {$[5]$} \\
\hline PCI after thrombolytic therapy & 0,8 & {$[5]$} \\
\hline CABG after thrombolytic therapy & 0,2 & {$[5]$} \\
\hline \multicolumn{3}{|l|}{ Clinical effectiveness of health states } \\
\hline Alive with $\mathrm{HI}$ in the first year & 0,701 & {$[5]$} \\
\hline Alive with $\mathrm{HI}$ in the second+ year & 0,683 & [5] \\
\hline Nonfatal myocardial infarction in the first year & 0,683 & {$[5]$} \\
\hline Nonfatal myocardial infarction in the second+ year & 0,718 & {$[5]$} \\
\hline Nonfatal stroke in the first+ year & 0,612 & {$[5]$} \\
\hline
\end{tabular}

PCI- percutaneous coronary intervention;

HI- heart insufficiency;

$\mathrm{CV}$ - cardiovascular;

MI- myocardial infarction;

CABG- coronary artery bypass graft.

$418007,29 \pm 158819,19 \mathrm{rsd}$ for $5,46 \pm 7,43$ QALYs $(76558,11 \mathrm{rsd}$ per QALY). Therefore, percutaneous coronary intervention was considered not to be cost effective assince it was two times more expensive per one QALY than thrombolytic therapy. The Monte Carlo simulation output is shown in Table 2. 


\begin{tabular}{|c|c|c|c|c|c|c|c|c|}
\hline & \multicolumn{4}{|c|}{ Percutaneous coronary intervention } & \multicolumn{4}{|c|}{ Thrombolytic therapy } \\
\hline & Mean \pm SD & Minimum & Median & Maximum & Mean \pm SD & Minimum & Median & Maximum \\
\hline Cost (rsd) & $\begin{array}{l}407685,01 \pm \\
158819,19\end{array}$ & 206706,39 & 360111,58 & 832951,99 & $\begin{array}{l}272085 \pm \\
139130,86\end{array}$ & 59132,85 & 253858,16 & 626066,25 \\
\hline $\begin{array}{l}\text { Clinical ef- } \\
\text { fectiveness } \\
\text { (QALY) }\end{array}$ & $5,17 \pm 7,43$ & 0 & 0 & 25,12 & $7,14 \pm 6,12$ & 0 & 6,34 & 15,73 \\
\hline ICER & \multicolumn{4}{|l|}{$-72201,92^{*}$} & \multicolumn{4}{|l|}{$1 * *$} \\
\hline
\end{tabular}

SD- standard deviation;rsd- Republic of Serbia dinars; QALY- quality-adjusted life years; *- PCI is considered as the alternative therapeutic method; ** - thrombolytic therapy is used as the standard therapeutic method.

The difference in costs between these two therapeutic methods is high, mostly because of the high initial cost. More than $30 \%$ of the percutaneous coronary intervention costs are related to the intervention itself and adjuvant therapy (glycoprotein IIb/IIIa inhibitors). However, the high initial costs in thrombolytic therapy were related to the price of the thrombolytic drug or, in our case, streptokinase. The difference in clinical effectiveness was not as high as expected, according to the data from other phar-

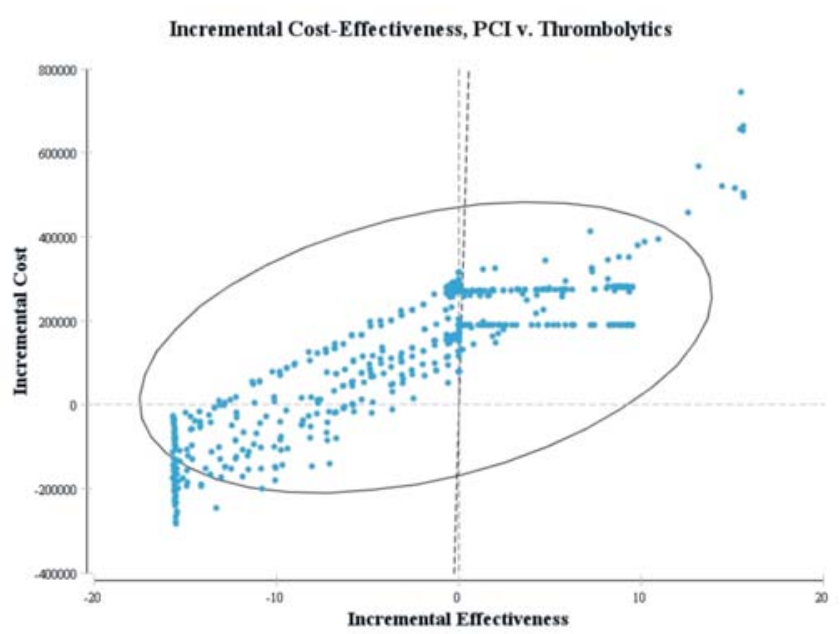

Figure 2. ICE Scatterplot of PCI vs. Thrombolytics

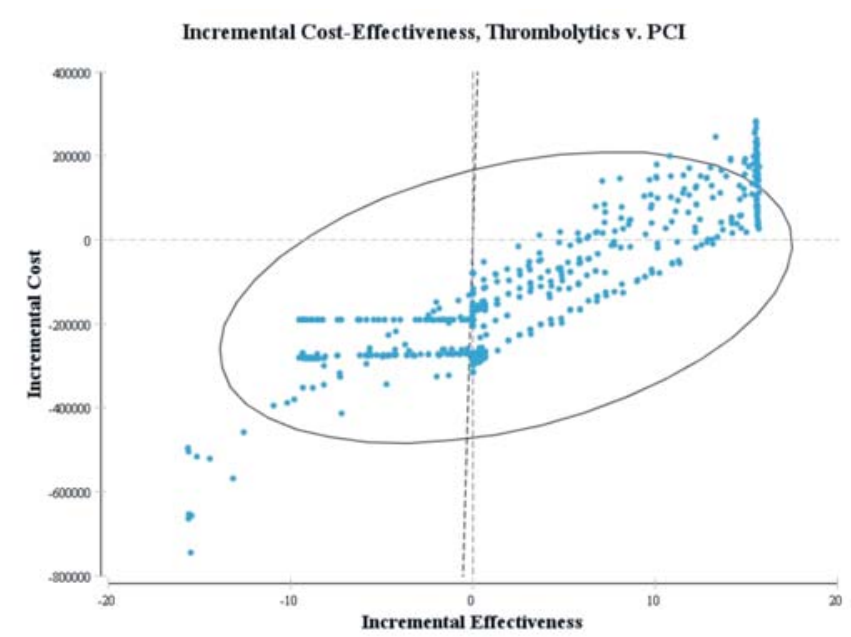

Figure 3. ICE Scatterplot of Thrombolytics vs. PCI maco-economic studies. In our study, the difference was 1,96 QALYs (7,42 QALYs for thrombolytic therapy versus 5,46 QALYs for PCI). The distribution of incremental costeffectiveness ratios (ICER) for these two treatment approaches for ST-elevated myocardial infarctions is shown in Figures 2 and 3.

For therapeutic options, the PCI-calculated ICERs for the majority of virtual patients are found in quadrant II, as shown at the scatterplots (Figure 2). This finding explains why coronary intervention is not cost effective. Coronary intervention has a low effectiveness and high cost, which is categorised as the worst treatment scenario economically. Because this therapy is above the willingness-to-pay threshold, it should be rejected as a therapeutic method. However, the thrombolytic therapy ICERs are mostly found in quadrant IV, where the effectiveness is high and costs are low. Because they are below the willingness-topay threshold, thrombolytics should be accepted as the therapeutic choice for myocardial infarctions.

A sensitivity analysis has shown that the initial costs of the primary PCI and repeated revascularisations are the most influential parameters. This finding confirms that the largest share of PCI costs are directed toward the intervention and the potential need for revascularisation. The negative net benefit suggests that the costs of PCI exceed the intervention's effectiveness. Even after varying parameters by $\pm 50 \%$, percutaneous coronary intervention did not become economically viable with positive net benefits.

\section{DISCUSSION}

The results of this study indicate that percutaneous coronary intervention is not as cost effective as thrombolytic therapy, i.e., streptokinase, for the treatment of STelevated acute myocardial infarctions. Some authors have reported that coronary intervention has a better cost-effectiveness ratio than thrombolytic therapy . [6] However, in our research, coronary intervention is more expensive but more effective, 7,12 QALY's as compared with 6,83 QALY's for thrombolytic therapy. The difference in gained quality adjusted life years in our study, 1,96 QALYs, favours thrombolytic therapy . Regarding cost, percutaneous coronary intervention is two times more expensive than 
thrombolytic therapy per one QALY gained. Our results were compared with other valid studies that analysed the cost effectiveness of these two treatment methods. In one study, the cost effectiveness of coronary interventions related to thethe time delay of the procedure was investigated.[6] If the time delay was 30 minutes or less, coronary intervention was cost effective and had a lower mortality and incidence of re-infarction. But with an increased delay (30-90 minutes), coronary intervention had a seven times higher cost-effectiveness ratio, which did not justify the intervention.[6] Time delay was no't investigated in our study, which is a study limitation. A valid systematic review article also has demonstrated the economic viability and clinical effectiveness of percutaneous coronary intervention. [13] With small statistically significant differences in the costs and the important differences in clinical effectiveness, coronary intervention had an incremental costeffectiveness ratio between $268 £$ and $29093 £$ per QALY, depending on the length of hospitalisation, thrombolytic price and the location requiring "life-saving $\mathrm{PCI}$ " after primary thrombolytic therapy.[13] In our model, we also included the percentage of patients who required repeat revascularisations (CABG or repeat $\mathrm{PCI}$ ), thus increasing costs. Most studies had a short time horizon, mostly up to six months, without examining the possible economic effects of rehospitaliszation, health consequences and their treatments. Long-term benefits of PCI and thrombolytic therapy were investigated in one study for a period of $5 \pm 2$ years. [14] During this period, didboth the costs of $\mathrm{PCI}$ andincrease, its clinical effectiveness increased, which confirms the economic superiority of PCI.[14] Repeated revascularisation is a very important factor, with a significant influence on the results of the analysis.

Several studies have demonstrated that frequent revascularisations among patients treated with primary PCI or thrombolytic therapy. In one study, $16,9 \%$ of patients older than 65 years required one or more revascularisation during the one-year follow-up period. Each revascularisation costs more than $\$ 19000$, which, increases ethe cost by five times.[15] Our study partially included the possible complications of PCI, including the followingany major cardiovascular and cerebrovascular event (death, myocardial infarction, urgent revascularisation, stroke) and haemorrhages. The treatment of complications comprised 25,7\% of all direct costs of coronary interventions. Bleeding complications were not included in our research, although they appear in $7,9 \%$ of patients and can increase costs.[16]

Numerous studies have investigated the clinical effectiveness of PCI as compared with thrombolytic therapy. $[17,18,19,20,21]$ These studies expressed the clinical effectiveness as a reduction of mortality rate and re-infarction or stroke frequency. The results of most studies demonstrated that PCI had an increased clinical effectiveness, but the result of some studies who do not agree with this finding .[22,23] The limitation of these studies is the short follow-up period of 30 days, in contrast to our time horizon of 40 years. This longer time period may explain our

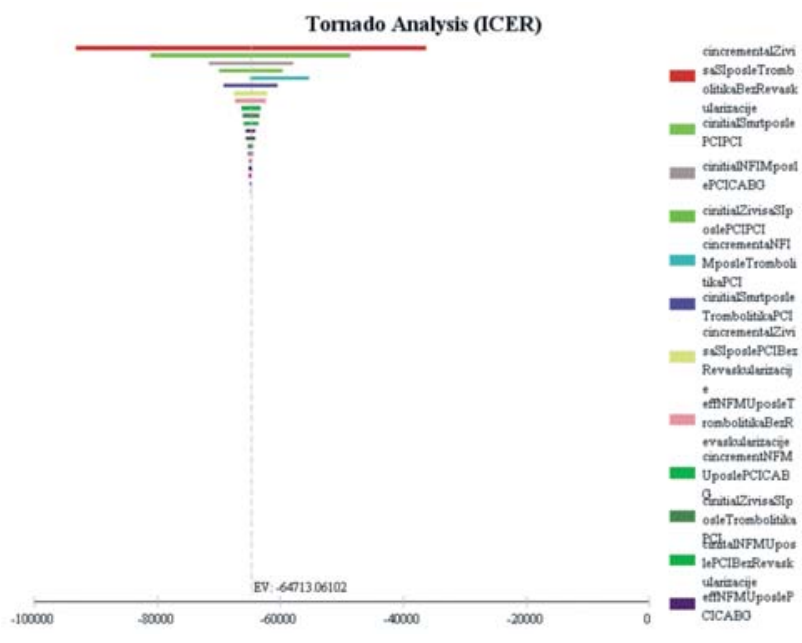

Figure 4. The multiple univariate analysis presented as a Tornado diagram

different results of a lower clinical effectiveness of PCI compared with thrombolytic therapy.

The results of our study can be explained by the health system in Republic of Serbia and the low drug prices compared with the high price of coronary interventions. The study limitations mentioned above also justify our costeffectiveness results. Similar results have been found in studies conducted in countries with well-organiszed health systems, such as England and Sweden. [23,24]

\section{CONCLUSION}

Our study suggests that percutaneous coronary intervention is not a cost-effective option for the treatment of myocardial infarction with ST elevations. Thrombolytic therapy with streptokinase has a higher clinic effectiveness and lower costs. Further research should be conducted to define the group of patients with acute myocardial infarction in Serbia whose condition economically justifies the use of percutaneous coronary intervention.

\section{REFERENCES}

1. Obradovic V. General consideration of myocardial infarction. In: Obradovic V. Acute myocardial infarctionclinic, diagnostic and treatment. Belgrade: Nikkard, 2007: 21-109. [In Serbian]

2. Health indicators in Republic of Serbia, Institute of Public Health of Serbia "Dr. Milan Jovanovic Batut", Informatics and Biostatistics Center, Belgrade 2009. (available at website: www.batut.org.rs,website last time visited: 23.06.2011.) [In Serbian]

3. National program for preventing, treating and controling cardiovascular diseases in Republic of Serbia until 2020. Regulation Act, Official Gazette 011/2010. (available at website: www.glasnikarhiva.rs, website last time visited 23.06.2011.) [In Serbian] 
4. Marc BM. Economics of Acute Myocardial Infarction. In: Califf RM, Braunwald MD. Atlas of heart diseases. Acute myocardial infarction and other acute ischemic syndromes. Vol VIII. Philadelphia: Current Medicine, 1996: 15.2-15.14.

5. Tree Age Pro, Healthcare software.

Release 0.78,2005;1988-2005 TreeAge Software

Inc. Available form: http:/ /www.treeage.com

6. Vegrel YB, Palmer S, Asserburg C et al. Is primary angioplasty cost effective in the UK? Results of a comprehensive decision analysis. Heart 2007; 93;1238-43.

7. Chew DP, Bhatt DL, Lincoff AM, Wolski K, Topol EJ. Clinical end point definitions after percutaneous coronary intervention and their relationship to late mortality: an assessment by attributable risk. Heart 2006; 92: 945-50.

8. Gershlick AH, Stephens-Llloyd A, Hughes S et al. Rescue Angioplasty after Failed Thrombolytic Therapy for Acute Miocardial Infarction. N Engl J Med 2005; 353: 2758-68.

9. Scottish Intercollegiate Guidelines Network SIGN. Guidelines. Acute coronary sindroms A national clinical guidelines. ( available at website: www.sign.ac.uk, website last time visited: 25.06.2011.)

10. Scottish Intercollegiate Guidelines Network SIGN. Guidelines. Management of patients with stroke or TIA: assessment, investigation, immediate management and secondary prevention. A national clinical guidelines. (available at website: www.sign.ac.uk, website last time visited: 21.06.2011.)

11. Scottish Intercollegiate Guidelines Network SIGN. Guidelines. Management of chronic heart failure. A national clinical guidelines. (available at website: www. sign.ac.uk, website last time visited: 21.06.2011.)

12. Anonymous. Tariff Book of Health Care Services in Health Facilities of Republic of Serbia. Belgrade: Republic Institute of Health Insurance, 2011.

13. Hartwell J, Colqutt J, Loveman E et al. Clinical effectiveness and cost-effectiveness of immediate angioplasty for acute myocardial infarction: systematic review and economic evaluation. Health Technology Assessment 2005; 9(17).

14. Zijlstra F, Hoorntje JCA, de Boer MJ et al. Long-term benefit of primary angioplasty as compared with thrombolytic therapy for acute myocardial infarction. N Eng J Med 1999; 341: 1413-19.

15. Clark MA, Bakhai A, Lacey MJ, Pelletier EM, Cohen DJ. Clinical and Economic Outcome of Percutaneous Coronary Intervention in Elderly: An Analysis of Medicare Claims Data. Circulation 2004; 110: 259-64.
16. Jacobson KM, Long KH, McMurtry EK, Naessens JM, Rihal CS. The economic burden of complications during percutaneous coronary intervention. Qual Saf Health Care 2007; 16: 154-59.

17. Boersma E and The Primary Coronary Angioplasty vs. Thrombolysis (PCAT)-2 Trialist Collaborative Group. Does time matter? A pooled analysis of randomized clinical trials comparing primary percutaneous coronary intervention and in-hospital fibrinolysis in acute myocardial infarction patients. European Heart Journal 2006; 27: 779-88.

18. Stenestrand U, Lindbäck J, Wallentin L. Long-term Outcomes of Primary Percutaneous Coronary Intervention vs Prehospital and In-hospital Thrombolysis for Patients With ST-Elevation Myocardial Infarction. JAMA 2006; 296: 1749-56.

19. Huynh T, Perron S, O'Loughlin J et al. Comparison of Primary Percutaneous Coronary Intervention and Fibrinolytic Therapy in ST-Segment-Elevation Myocardial Infarction: Bayesian Hierarchiacal Meta-Analyses of Randomized Controlles Trials and Observational Studies. Circulation 2009;119: 3101-09.

20. Andersen HR, Nilsen TT, Rasmussen K et al. A Comparisom of Coronary Angioplasty with Fibrinolytic Therapy in Acute Myocardial Infarction. N Eng J Med 2003; 349: 733-42.

21. Gao R, Han Y, Yang X et al. Thrombolytic therapy with rescue percutaneous coronary intervention versus primary percutaneous coronary intervention in patients with acute myocardial infarction: a multicenter randomized clinical trial. Chin Med J 2010; 123: 1365-72.

22. Aasa M, Henriksson M, Dellborg M et al. Cost and Health Outcome of Primary Percutaneous Coronary Intervention versus Thrombolysis in Acute ST-segment Elevation Myocardial Infarction - Results of the Swedish Early Decision Reperfusion Study (SWEDES) Trial. Am Heart J 2010; 160: 322-28.

23. Weintraub WS, Boden WE, Zhang Z et al. Cost-Effectivness of Percutaneous Coronary Intervention in Optimally Treated Stable Coronary Patients. Circ Cardiovasc Qual Outcomes 2008; 1: 12-20.

24. Fidan D, Unal B, Critchely J, Capewell S. Economic analysis of treatments reducing coronary heart disease mortality in England and Wales, 2000-2010. Q J Med 2007; 100: 277-89. 